\title{
The Croker Carbonate Slabs: extensive methane-derived authigenic carbonate in the Irish Sea-nature, origin, longevity and environmental significance
}

\author{
Alan Judd ${ }^{1}$ (D) $\cdot$ Tamsyn Noble-James ${ }^{2,3} \cdot$ Neil Golding ${ }^{2,4} \cdot$ Andrew Eggett $^{2} \cdot$ Markus Diesing $^{3,5} \cdot$ David Clare $^{3}$. \\ Briony Silburn ${ }^{3} \cdot$ Graeme Duncan $^{2} \cdot$ Lorraine Field $^{6} \cdot$ Antoni Milodowski $^{6}$
}

Received: 8 April 2019 / Accepted: 15 August 2019 / Published online: 10 September 2019

(C) The Author(s) 2019

\begin{abstract}
The Croker Carbonate Slabs, in the UK sector of the Irish Sea, has shallow (70 to $100 \mathrm{~m}$ ) water, strong (>2 knot) tidal currents, coarse mobile surficial sediments and the most extensive methane-derived authigenic carbonate (MDAC) known in European waters. Multi-disciplinary studies (2004 to 2015) were commissioned specifically to document the benthic habitat, and have resulted in the designation of this site as a Marine Protected Area (MPA) under the European Commission's Habitats Directive as an example of "Submarine structures formed by leaking gases". However, this paper is focussed on the geoscience aspects of the site: the mineralogy and isotopic composition of the MDAC, its formation and age. It considers the implications of these findings with respect to the timing of the deglaciation of the area since the Last Glacial Maximum (LGM), and the environmental implications of the seepage of methane from the site over a period of at least 17,000 years. Carbon isotope ratios $\left(\delta^{13} \mathrm{C}-34\right.$ to $-54 \%$ ) confirm that the carbonate minerals (high-Mg calcite and aragonite) result from the anaerobic oxidation of methane. Widespread shallow gas within post-glacial sediments is sourced from underlying coal-bearing Carboniferous strata. Geophysical (side-scan sonar and multi-beam echo sounder) and visual surveys show that the MDAC occurs as isolated lumps, continuous pavements, and cliffs $<6 \mathrm{~m}$ tall, which post-date the post-glacial sediments, but are in places covered by a veneer of coarse mobile surficial sediments. U-Th dates $(17,000 \pm 5500$ to $4000 \pm 200 \mathrm{BP})$ suggest continual MDAC formation since the last glacial maximum, and constrain the postglacial sea level rise in this part of the Irish Sea; the site must have been submarine before MDAC formation started, whether or not methane was escaping. Visual and acoustic evidence of gas seepage is limited, but methane concentrations in the water are high $\left(<21.4 \mathrm{nmol}^{-1}\right)$ and suggest present-day export to the atmosphere. It is also implied that significant methane release to the atmosphere occurred immediately after the retreat of the ice that covered the site during the LGM until 21.9 to $20.7 \mathrm{ka}$ BP.
\end{abstract}

Keywords Methane-derived authigenic carbonate (MDAC) · Irish Sea · Methane · Shallow gas · Gas seepage · Benthic ecology · Marine Protected Area

Electronic supplementary material The online version of this article (https://doi.org/10.1007/s00367-019-00584-0) contains supplementary material, which is available to authorized users.

Alan Judd

alan.judd@icloud.com

Alan Judd Partnership, High Mickley, Northumberland, UK

2 Joint Nature Conservation Committee, Peterborough, UK

3 Centre for Environment, Fisheries and Aquaculture Science, Lowestoft, UK
4 South Atlantic Environmental Research Institute (SAERI), Stanley, Falkland Islands

5 Norges Geologiske Undersøkelse, Trondheim, Norway

6 British Geological Survey, Keyworth, Nottingham, UK 


\section{Introduction}

Methane-derived authigenic carbonate (MDAC) is a byproduct of natural seabed methane seepage. It forms as a consequence of the anaerobic oxidation of methane (AOM) coupled with sulphate reduction in the sulphate-methane transition zone (SMTZ) by consortia of sulphate-reducing bacteria and methane-utilizing archaea (Boetius et al. 2000; Boetius and Wenzhöfer 2013). By-products of this process, hydrogen sulphide $\left(\mathrm{HS}^{-}\right)$and bi-carbonate $\left(\mathrm{HCO}_{3}{ }^{-}\right)$, react with iron and calcium, respectively, to form pyrite $\left(\mathrm{FeS}_{2}\right)$ and calcium carbonate $\left(\mathrm{CaCO}_{3}\right)$ within the pore spaces of the sediment; $\mathrm{CaCO}_{3}$ binds the pre-existing sediment matrix to form a hard rock-like substance, MDAC (Hovland et al. 1987; Aloisi et al. 2002). The SMTZ normally lies close beneath the seabed, but MDAC may be exposed on the surface following sediment removal or erosion, or where methane fluxes are high. In the deep (>300 $\mathrm{m}$ or so) waters beyond the continental shelf, methane seeps are commonly associated with chemosynthetic organisms that utilize the methane and/or the $\mathrm{H}_{2} \mathrm{~S}$, and which may support dense biological communities on an otherwisebarren seabed. However, in the shallower waters of continental shelves, these seep-specialist organisms tend to be outcompeted by 'normal' benthic organisms that ultimately derive their energy from photosynthetic sources. Yet, where exposed or thinly covered, MDAC provides a substrate significantly harder than the normal seabed that may be colonized to form benthic communities that are atypical of the surrounding area (Judd and Hovland 2007; Dando 2010).

MDAC has been described from numerous natural seabed methane seep sites worldwide, in a variety of geological and oceanographic settings (Judd and Hovland 2007). It is confined by the seabed plumbing system to the immediate vicinity of methane seeps, so its occurrence is generally localized. In deep waters, MDAC occurrences may be extensive (Levin et al. 2016). However, on continental shelves where seabed processes may have been disrupted during glacial periods, either by the occurrence of ice, or because of the changes in surface processes caused by sea level fall and rise, extensive MDAC is less likely; indeed at other reported shelf occurrences, MDAC seems to be quite limited in extent (Judd and Hovland 2007); no extensive occurrences have come to the attention of the authors. Around the British Isles, MDAC has been reported in various geological contexts (Judd and Hovland 2007; see Fig. 1), in the majority of cases, it is present as isolated lumps or small concentrations distributed across the seabed. However, in some places, MDAC is more widespread (Fig. 1):

- at Holden's Reefs in Tremadog Bay MDAC occupies approximately $40,000 \mathrm{~m}^{2}$ of a $3.4 \mathrm{~km}^{2}$ area within the Pen Llŷn a'r Sarnau Special Area of Conservation (SAC). These are associated with methane rising from Tertiary peats and/or oil and gas-prone Jurassic mudstones (Judd et al. 2007).

- In the Irish sector of the Irish Sea, there are 23 elongate MDAC mounds along the Codling Fault Zone. Typically, these are $>250-\mathrm{m}$ long and 80-m wide, occupy areas of $>$ $20,000 \mathrm{~m}^{2}$ and stand 5-10 $\mathrm{m}$ above the general seabed (O'Reilly et al. 2014). These features lie within the Codling Fault Zone SAC (NPWS 2015).

This paper concerns another Irish Sea site in the UK sector, first identified as being of interest during the Strategic Environmental Assessment of the Irish Sea (SEA6) when MDAC was found to be present over an area estimated to be $>500,000 \mathrm{~m}^{2}$ (Judd 2005, and Judd et al. 2007). Subsequent investigations by the UK's Joint Nature Conservation Committee (JNCC) and the Centre for Environment, Fisheries and Aquaculture Science (Cefas) on behalf of the UK Government (Whomersley et al. 2010; Wood et al. 2016; Noble-James et al. 2017, 2019), demonstrated that MDAC is present over a much wider area. The principal objectives of these investigations were to confirm that the hardgrounds in this area are indeed MDAC, to determine the extent of the MDAC, to determine the suitability of the site for designation as an MPA, and to undertake baseline studies as the initial part of a long-term ecological monitoring programme. This area is now referred to as the Croker Carbonate Slabs (CCS) and, alongside 26 other sites in European waters, has been designated as a Marine Protected Area (MPA) for its MDAC habitats, termed 'Submarine structures made by leaking gases' under the EC Habitats Directive. Details of the benthic communities and strategies for monitoring MDAC habitats are presented in a parallel publication (Noble-James et al. 2019). This paper focuses on the geological and environmental context, the origin of the gas responsible for MDAC formation, the age of the MDAC and the environmental conditions under which it formed with specific reference to the development of the site since the last glacial maximum. It presents a revised interpretation of the areal extent of the MDAC, and presents new evidence of current gas escape activity and the consequential increase in methane concentrations in the water column with implications for methane release to the atmosphere. This study is based primarily on data acquired during a multi-disciplinary survey undertaken by JNCC and Cefas in 2015, and also draws on data acquired in previous surveys (2004, 2008 and 2012/13).

\section{Site location and geological context}

The CCS site is located approximately $30 \mathrm{~km}$ northwest of the Welsh island of Anglesey (Fig. 1). It occupies an inclined plateau lying in about $70 \mathrm{~m}$ water depth in the north and about 

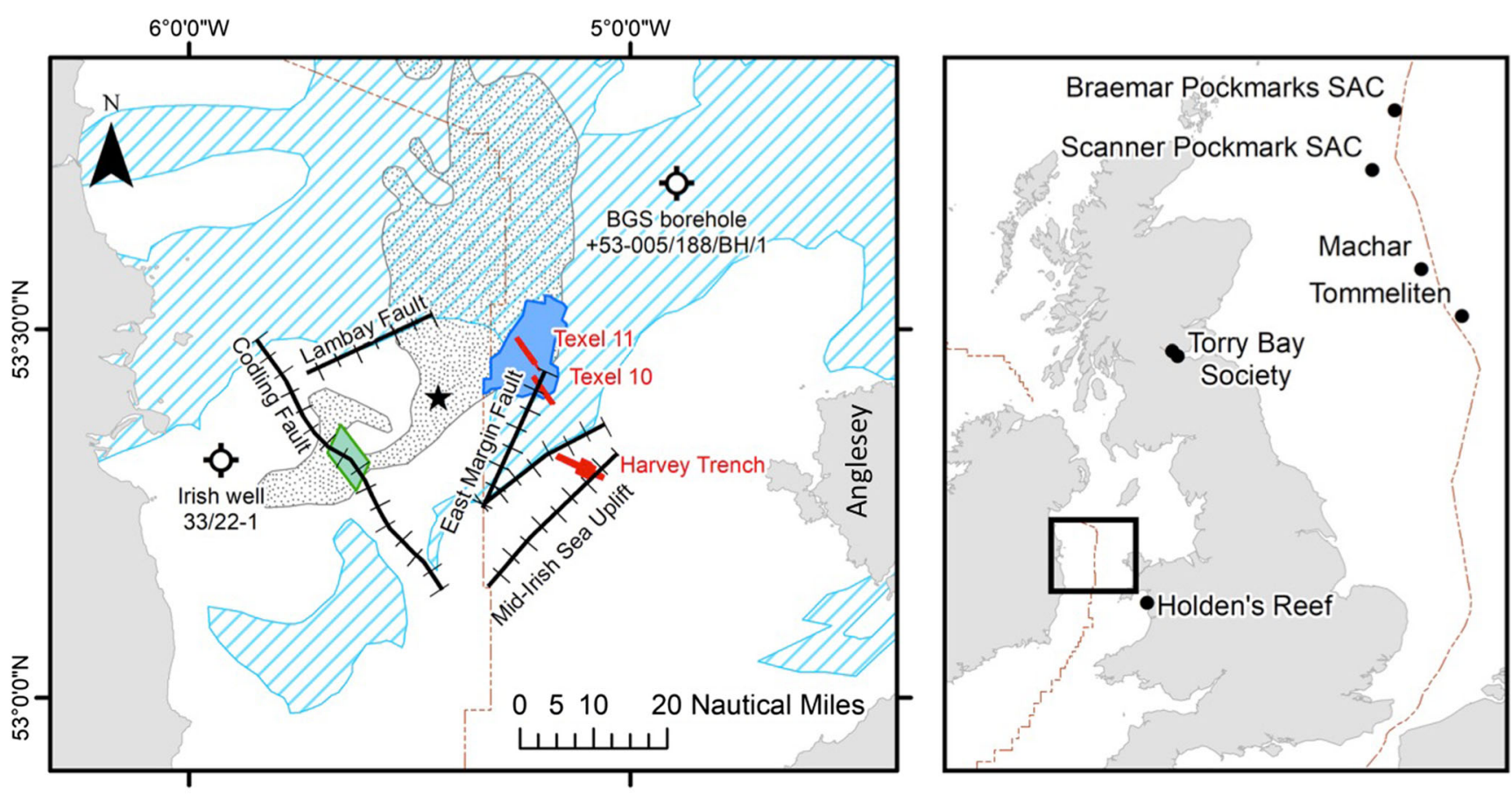

\section{Legend}

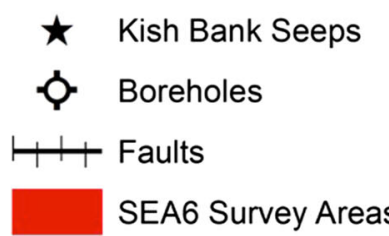

Fig. 1 Location of the Croker Carbonate Slabs site. For details of key MDAC sites see: Andrews 1988 (Society); Gafeira and Long 2015a (Braemar Pockmarks SAC); Gafeira and Long 2015b (Scanner

\section{Extent of Gas-blanking}

\section{Extent of Carboniferous Geology}

Codling Fault SAC

\section{Croker Carbonate Slabs SAC}

$100 \mathrm{~m}$ deep in the southwest. This plateau is punctuated in places by hollows of relatively deep $(<110 \mathrm{~m})$ water. There is deeper water to the west and south, and to the east there is a 3.5-km wide and 24-km-long channel where water depths exceed $180 \mathrm{~m}$ in places. Strong tidal currents, estimated to exceed two knots ( $\sim \mathrm{m} \mathrm{sec}^{-1}$; Holmes and Tappin 2005), have a significant effect both on the nature of the seabed sediments, and on survey operations.

There is little detailed information on the underlying geology of the CCS site. British Geological Survey (BGS) information from this area is based mainly on seismic reflection (airgun and sparker) data acquired during the 1960s and 1970s. The understanding of the geological composition of the survey area is therefore based on the available data and interpolation from surrounding areas (IGS and GSI 1982; Wingfield et al. 1990; British Geological Survey 1994; Jackson et al. 1995; Croker 1995; Croker et al. 2005; Mellett et al. 2015) which indicate that the survey area is underlain by rocks of Carboniferous age; Westphalian in the south of the area,
Pockmark SAC); Judd et al. 2002 (Torry Bay); Judd et al. 2007 (Holden's Reef); Niemann et al. 2005 (Tommeliten); Salisbury 1990 (Machar)

and undifferentiated Silesian (Namurian and Westphalian) further north (IGS and GSI 1982; Jackson et al. 1995). The $720 \mathrm{~m}$ of Westphalian rocks encountered in well 33/22-1 (Irish sector; on the margin of the Kish Bank Basin) included $19 \mathrm{~m}$ of thermally-mature bituminous coal (Croker 1995). BGS borehole + 53-005/188/BH/1 (in the Quadrant 109 Syncline) penetrated $>26 \mathrm{~m}$ of grey Silesian mudstone with thin coals within $62 \mathrm{~m}$ of the seabed (British Geological Survey 1994; British Geological Survey: Geoindex Offshore n.d.). Croker (1995) considered that Carboniferous rocks, particularly the Coal Measures (Westphalian) and the Holywell Shale (Dinantian/Namurian), to be the principal gas sources in the Irish Sea, and that all the known gas occurrences and migration features (including CCS, Kish Bank and the Codling Fault carbonate mounds) occur where the Carboniferous subcrops beneath the Quaternary, or where faults provide possible migration pathways.

The Carboniferous rocks are unconformably overlain by much younger sediments. Undivided Neogene/Paleogene sediments are present in the southwest of the area (IGS and GSI 
1982), and Pleistocene sediments are present over the whole survey area (Wingfield et al. 1990; Jackson et al. 1995; Mellett et al. 2015). The Pleistocene sediments of this area are attributed to the Prograded Facies (PF), part of the late-Weichselian Western Irish Sea Formation. These are described as silt-rich muds (greenish-grey to black in colour), sandy in places and with occasional gravel, cobble and boulder patches, deposited in a cold water (freshwater to marine), pro-deltaic to glaciomarine environment (Jackson et al. 1995; Mellett et al. 2015). Their northwesterly dip implies a source to the southeast (i.e. Anglesey and the mainland of North Wales). The PF may be underlain the Upper Till (UT) member of the Cardigan Bay Formation (Weichselian), described by Jackson et al. (1995) as a stiff or hard clay containing clasts of various sizes from sand to boulders. Gas blanking obscures the lower part of seismic records over a wide area (Fig. 1), including most of the CCS survey area (Wingfield et al. 1990; Jackson et al. 1995). Holocene sediments of the Surface Sands Formation (SSF) lie on an erosion surface that truncates the PF, from which it is probably derived. The SSF, is generally thin, patchy or completely absent, but attains a thickness of $25 \mathrm{~m}$ to the southwest of the CCS area (Wingfield et al. 1990). It comprises three layers. The oldest, Layer C, is described as relict Quaternary sediment or solid rock. Layer B comprises a discontinuous lag deposit of coquina, shelly gravel, and coarse sand, the finer clean sands having been winnowed away to form the surficial sands of Layer A. These are highly mobile under the prevailing current conditions and, in places, form sandwaves and mega-ripples (Jackson et al. 1995).

The seabed in this part of the Irish Sea is a complex mixture of features indicative of sediment transport and erosion: sandwaves, deep water trenches, etc. Harvey Trench, south of CCS (see Fig. 1) is at least $5 \mathrm{~km}$ wide, and, in places, > $80 \mathrm{~m}$ deeper than the surrounding plateau, with cliff-like sidewalls $>30 \mathrm{~m}$ high. Trochoidal sandwaves within the trench are $<1.4 \mathrm{~km}$ long, $<120 \mathrm{~m}$ wide and $<15 \mathrm{~m}$ high (Judd 2005). Sandwaves on the plateau north of CCS are smaller in scale. To the northeast Van Landeghem et al. (2009) described a previously glaciated seabed with features (ribbed moraines, drumlins, flutes and eskers) characteristic of sub-glacial and ice-marginal environments.

\section{Methods - survey operations and post-processing}

The data used here were acquired in October-November 2015 during the joint JNCC and Cefas survey onboard the R/V Cefas Endeavour. Previously acquired acoustic and groundtruthing datasets, and sample analyses acquired in 2004 (Judd 2005), 2008 (Whomersley et al. 2010), and 2012/13 (Callaway et al. 2015) were used in the planning of this survey, and to supplement the 2015 data where appropriate. The
2004, 2008 and 2012/3 data, along with geographical, bathymetric and other general data, were compiled on a GIS system prior to the 2015 survey, and were used to position physical and remote data acquisition locations in areas where no further acoustic data would be acquired (see Wood et al. 2016 and Noble-James et al. 2017). Newly acquired data, uploaded as they became available during the survey, were used for initial interpretation and decision-making. For example, acoustic survey lines were planned to infill existing data gaps, seabed imagery transects were planned according to the nature of the seabed and sub-seabed as seen on the acoustic data, and sampling stations were selected to provide representative samples. Details of the survey equipment and techniques are detailed by Wood et al. (2016).

The general workflow was as follows, each step guiding the planning of the next: acquisition, processing and review of acoustic data; acquisition and review of seabed images; acquisition of seabed samples, sieving and preservation for onshore analysis; acquisition of water samples and preservation for onshore analysis. Logistical considerations meant that data were not always acquired in this order.

Acoustic data Sub-bottom profiler (SBP) data were acquired using a Geoforce deep-towed boomer $(0.5-8 \mathrm{kHZ})$ operating sometimes at low (135 J) and sometimes at high (240 J) power to achieve the best possible balance between resolution and sub-bottom penetration; line coverage is shown in Fig. S1a. Vessel speed was notably influenced by the high current speed; to ensure high-quality output, lines were run in the appropriate direction to ensure a suitable speed over the ground with a vessel speed of $4-5$ knots $\left(\sim 2-2.6 \mathrm{~m} \mathrm{sec}^{-1}\right)$. Layback application, processing and interpretation of the data were undertaken onboard during the survey to inform the prioritization of ground-truthing activities. Singlebeam (Simrad EK60) scientific echosounder (ES) and Kongsberg EM2040 multi-beam echosounder (MBES) were deployed continuously and simultaneously throughout acoustic survey operations. Edgetech 4800MP 300/600 kHz dual frequency digital sidescan sonar (SSS) data were acquired to assess the texture and dimensions of hard substrates in areas of high MBES backscatter intensity, for which SSS data had not been previously acquired. The SSS system was also used to investigate areas of gas seepage, with water column targets being visible on the water column section of the SSS trace. All acoustic data were processed and quality assured during the survey by Cefas with the exception of the SBP data, which was processed by Exploration Electronics Ltd. Details of the various acoustic methods used and their interpretation are provided by Wood et al. (2016).

Seabed imagery A total of 128 drop frame camera transects were undertaken (see Fig. S1b), each acquiring video and still imagery data using an STR SeaSpyder 'Telemetry' Drop 
Camera System which was towed whilst the ship moved slowly in the required direction. Seabed images were subsequently processed in order to evaluate the distribution of MDAC and the associated epifauna (see Noble-James et al. (2017) for details).

Seabed sampling Sediment samples were taken from 56 locations (Fig. S1c) across the survey area using a $0.1-\mathrm{m}^{2} \mathrm{mini}$ Hamon grab; $0.1-\mathrm{m}^{2}$ Day grab samples were taken at three stations. The Hamon grab samples were sub-sampled for particle size analysis (PSA) and sieved over a 1-mm mesh to retain macrofauna. The Day grab samples were sub-sampled for PSA and meiofauna. Suspected MDAC samples were retained for analysis following onboard carbonate testing using $10 \%$ hydrochloric acid. PSA, macrofaunal, meiofaunal and potential MDAC samples were processed onboard the vessel according to the methods described by Wood et al. (2016) prior to analysis onshore.

Seabed mapping Geographic Object-Based Image Analysis (GEOBIA) routine was conducted using eCognition v9.2.1 software to map the predicted extent of MDAC, as summarized in Supplementary Text 1, and detailed in Noble-James et al. (2017: Annex 4). The resulting map, which combined acoustic data from the 2008, 2012/13 and 2015 surveys and the locations of confirmed MDAC samples, shows areas of 'high confidence MDAC' and 'potential MDAC'.

MDAC analyses Samples of potential MDAC were retained from 30 locations (see Fig. 2c) and submitted to the BGS for petrological, mineralogical, and isotope analysis; of these, some were selected for strontium isotope $\left({ }^{87} \mathrm{Sr} /{ }^{86} \mathrm{Sr}\right)$ analysis and/or U-Th age dating. X-ray diffraction (XRD), optical microscopy and backscatter scanning electron microscopy (BSEM), including energy-dispersive X-ray microanalysis (EDXA) were undertaken primarily in order to characterize the carbonate cements, including mineralogical composition. Carbon $\left(\delta^{13} \mathrm{C}\right)$ and oxygen $\left(\delta^{18} \mathrm{O}\right)$ stable isotope analyses were performed by mass spectrometry on 127 sub-samples, acquired by micro-drilling carbonate minerals within the potential MDAC samples. These analyses were undertaken to provide indications of the origin of the carbon in the cements, and the seawater temperature at the time of cement formation, respectively. ${ }^{87} \mathrm{Sr} /{ }^{86} \mathrm{Sr}$ analyses were conducted in order to establish the source of pore fluids. Eight 1 to $10 \mathrm{mg}$ samples of pure aragonite were carefully handpicked or micro-drilled from five selected MDAC samples, and from modern calcareous serpulid encrustations and shelly fragments used for reference purposes. The number of U-Th age dates acquired was limited because of the intermixing of silica-rich detritus with the carbonate minerals acquired by micro-drilling from previously-prepared polished sample block. Isotope ratio measurements were made by Inductively Coupled Plasma
Mass Spectrometry (ICP-MS). The procedures used in these analyses are detailed in Field et al. (2016a and b; 2017), and in the Supplementary Text 2.

Methane concentration in seawater A pump-driven molecular electronic transducer (METS) methane detector system was attached to the camera drop-frame to measure variations in methane concentration in the water column; it was operated continuously during 127 camera deployments. The sensor was left running whilst being deployed and recovered; between stations it was immersed in seawater to stabilize. Methane concentration data were collected as voltages, which were then used to calculate methane concentration in nmol $1^{-1}$ using software provided with the sensor. Data were recorded at $5 \mathrm{~s}$ intervals for the duration of each camera transect, and averages of methane concentration per minute were then calculated. Water sampling was undertaken to provide validation of the METS sensor readings. Samples were taken at six stations (Fig. S1d) using a 101 Niskin bottle. Three samples were taken within the survey site where METS sensor, ES, MBES or visual data suggested possible gas seepage. In addition, three control samples were acquired; one adjacent to the site and two at locations outside the survey area. At each sampling location, three water samples were taken: one just above the seabed, one mid-water and one just below the sea surface. Further information on methane sampling procedures is available in Wood et al. (2016). Water samples were processed by Newcastle University using a modified version of the method detailed in Upstill-Goddard et al. (1996).

\section{Results}

Sub-seabed The boomer profiles indicate the presence of two sediment packages (Units A and B) within the survey area (Fig. 2). Unit B, the older (lower) package, present throughout the survey area and with a true vertical thickness of $>30 \mathrm{~m}$, comprises multi-layered sediments, the layering being represented by numerous parallel internal reflections. The younger Unit A lies unconformably on the eroded Unit B surface (Fig. 2 inset a). On the eastern side of the site, it is not present, or is too thin to be identified on the boomer profiles, but it attains a thickness of $>15 \mathrm{~m}$ in the west. The bedding, which dips towards the northwest, is steeper on the western side of the site where the younger (Unit A) sediments occur at the seabed. The older members of Unit B are exposed in the deep-water channel to the east of the site, and in the sidewalls of the hollows. The boomer profile presented in Fig. 2 was located over a geological cross-section (Section 1 of Wingfield et al. 1990) to enable correlation with the stratigraphy of a wider area. Unit A most likely represents the Wave and Bank Facies of the Surface Sands Formation (Holocene). Because of the seismic character, thickness and geographical extent of Unit 


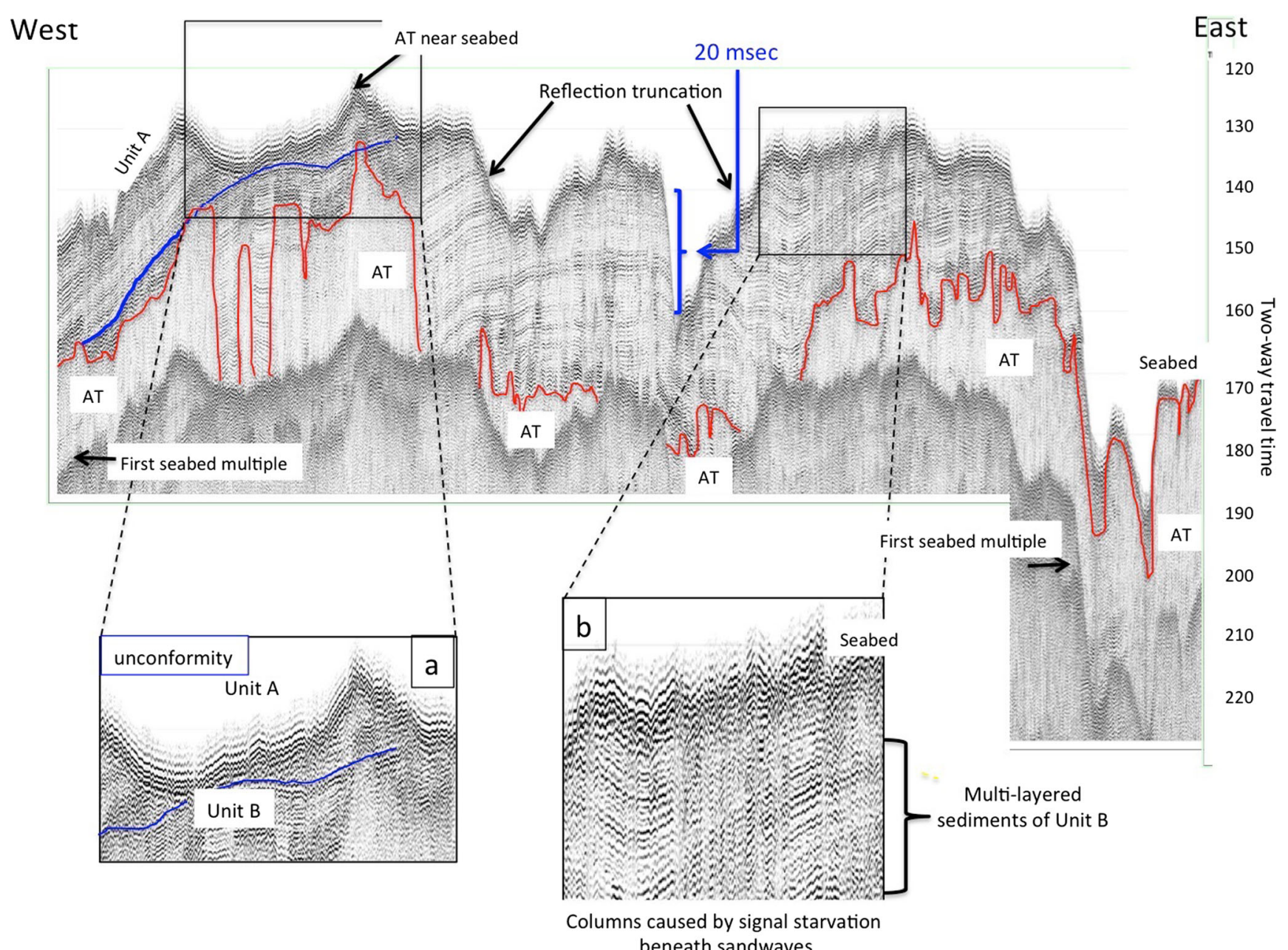

Fig. 2 Boomer data example (SBP009) - the stratigraphy of the study area (for location see Fig. 3). Unit A is equated to the Wave and Bank Facies of the Surface Sands Formation (Holocene), and Unit B to the Prograded Facies of the of Western Irish Sea Formation (Weichselian)

B, it is assumed that it represents the Prograded Facies of the Western Irish Sea Formation, as described by Wingfield et al. (1990) and Jackson et al. (1995). Erosion of the deep-water channel to the east of the site, and hollows within the main plateau area of the site has exposed a $\sim 30 \mathrm{~m}$ gross vertical section through these sediments.

The reflections evident on the profiles were obscured by acoustic turbidity (AT on Figs. 2 and S2), which is commonly attributed to the presence of gas within sediments (Judd and Hovland 2007). The presence of gas is further indicated by increased amplitude of some individual reflections; this is referred to as gas brightening, and suggests an increased concentration of gas within the affected sediments, and that gas is channelled laterally and up dip (Judd and Hovland 2007). If so, the dominant direction of gas migration is from northwest to southeast. AT is present over almost the whole survey area, indeed CCS is a small part of a larger area of AT indicated by Wingfield et al. (1990; see Fig. 1). However, there are gas-free 'windows' beneath some of the seabed hollows (see Fig. S2). of Wingfield et al. (1990) and Jackson et al. (1995). AT = acoustic turbidity, an indicator of gas. Reflection truncation: $>15 \mathrm{~m}(\sim 20 \mathrm{msec})$ of PF sediments have been removed by erosion

These windows may suggest that gas has not accumulated in these areas, or more likely, that gas once present has already escaped. Where gas accumulates in the sediments, layering is obscured by AT. At certain locations, AT (gas) penetrates vertically towards the seabed, forming gas chimneys (vertical columns of AT). Residual gas continues to migrate laterally and up dip, causing gas brightening. Some gas chimneys rise only part way to the seabed; others rise to, or very close to it, apparently affecting the character of the seabed which appears to be more rugged than elsewhere. In some places the AT signature may be mistaken for reductions in signal strength caused by marked acoustic impendence contrasts between seawater and a hard, shelly or pebbly seabed, or by sandwaves; signal starvation may also be caused by the scattering of incident acoustic energy by sandwaves (Fig. S2).

Seabed MBES and SSS mapping of the site and surrounding area shows that much of the CCS area occupies a plateau with water depths ranging from $\sim 70$ (in the northeast) to $\sim 100 \mathrm{~m}$ 
(in the southwest). This plateau continues to the north and west of the CCS area, albeit at a generally lower elevation. It slopes to the south, and the water depth increases significantly beyond the CCS area. To the east, the plateau is bounded by a deep $(>125 \mathrm{~m})$ channel, the plateau edge being marked by steep slopes and, in places, cliff-like features (see Figs. 3 and S2). Hollows that punctuate the plateau are described separately. Various types of bedform, feature and substrate within the site indicate a seabed of considerable complexity commensurate with the moderate to high-energy hydrodynamic regime. PSA shows that the sediments are dominated by sand; silt/clay is present in increasing amounts away from the shallower plateau area in the northeast. A few samples from deeper parts of the area include 25 to $50 \%$ silt/clay. For PSA details, see Noble-James et al. (2017). The water was often extremely turbid with suspended sediment impairing visibility during camera tows. For convenience, the area is described as comprising areas of (acoustically) 'soft', relatively smooth, seabed characterized by surficial sediments and acoustically 'hard' areas with MDAC. In each case, the seabed is described with reference to the acoustic mapping, the visual observations and the sampling.
Soft seabed Areas of relatively smooth, acoustically 'soft' seabed are generally characterized by surficial sands and sandwaves described above as Unit A, and believed to be representative of the Holocene SSF. Generally, the seabed sediments are loose, rippled sands with occasional patches of shelly material (Fig. S3a). Superimposed on this surface are larger sandwaves composed of cleaner sands (Fig. S3b), which are individually identifiable on the MBES data. Three main types of sandwaves (indicated in Fig. 3) are present: (S1) relatively small sinusoidal features, (S2) long, bifurcating sinusoidal sandwaves found mainly on the plateau in the north of the survey area and (S3) large symmetrical trochoidal features found within the deep-water channel and hollows. These mobile features may, from time to time, cover or reveal exposures of MDAC. A more detailed investigation of the sandwaves in this part of the Irish Sea was presented by Van Landeghem et al. (2009).

Where the loose, rippled sands are absent the sediment comprises loose, poorly sorted sand (from fine to coarse grained) with a large proportion of gravel, broken shells and/ or whole shells interspersed (Fig. S3c) with rippled sand and occasional large clasts (Fig. S3d), some of which are

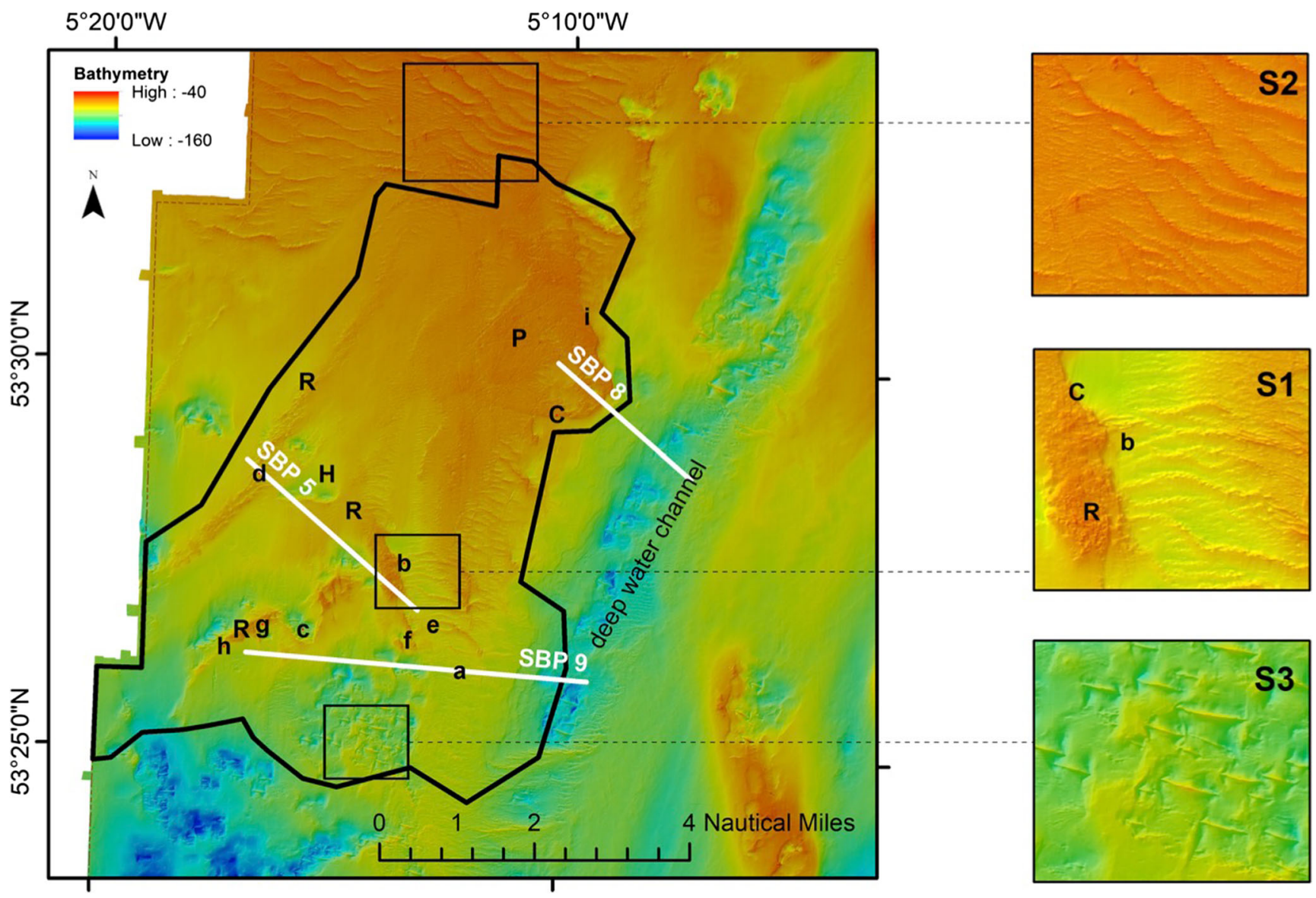

Fig. 3 MBES image of the CCS survey area showing the main seabed features. $\mathrm{C}=$ 'cliff'; $\mathrm{H}=$ Hollow; $\mathrm{P}=$ Plateau; $\mathrm{R}=$ Ridge. $\mathrm{a}-\mathrm{i}=$ locations of seabed images shown in Fig. S3. SBP 5, 8 and 9 are the sub-bottom profiles shown in Figs. 2 and S2. Inset: three types of sandwaves (S1, S2 \& S3) discussed in the text 
tentatively identified as glacial dropstones (Fig. S3e). Some dropstone examples, collected during bottom sampling, were tentatively identified as micaceous schist, gritstone and phyllite. They were probably derived most recently from the Unit B sediments, examples of which are also exposed in places; previously they may have been held within diamict deposited from the Irish Sea Ice Sheet, but ultimately, they were probably from the Lower Palaeozoic and Ediacaran of North Wales, or the Dalradian of southwest Scotland. In places, these surficial sediments are absent and patches or exposures of blue-grey clayey material are revealed. This material has not been sampled, but exposures (e.g. S3f) show that it has sufficient strength to remain freestanding when fully exposed or undercut. This may be representative of the UT.

Hard seabed - MDAC The 'hard' areas, which have a relatively high acoustic reflectivity and (subjectively) a stippled appearance on MBES, dominate the north-eastern part of the CCS, but are also present elsewhere, for example in the ridge which extends approximately north-south on the western side of the area. The seabed is generally not smooth, sometimes quite rugged, and characterized by exposures of hard, rock-like material with or without a veneer of surficial sandy sediments of Unit A (see Fig. S3g). Samples of the rock-like material proved to be MDAC (analytical results are presented below). Where physical samples could not be acquired, areas of potential MDAC were identified with reasonable confidence from seabed imagery because of its characteristic physical appearance. The topographical characteristics of MDAC varied along a continuum, with observations assigned to one of two classes: 'low' (flat) or 'high' (rugged) relief (see Figs. S3h and S3i respectively). Generally, the high relief MDAC has an elevation of $>20 \mathrm{~cm}$, and in places up to $6 \mathrm{~m}$, above the surrounding sediment. The high relief MDAC is generally colonized by a prolific and diverse epifauna; the same epifaunal taxa are generally present but less prolific on the low relief MDAC (which in many instances is covered by a thin veneer of sediment), and absent from the surrounding sediment. The epifauna are briefly described below, and in more detail by Noble-James et al. (2017 and 2019). The distribution of MDAC, estimated by combined mapping of all available habitat models using the MBES and SSS data (Duncan 2018), is presented in Fig. 4a. Within the $116-\mathrm{km}^{2}$ area of the CCS site, there is 'high confidence' that MDAC is present over $20 \mathrm{~km}^{2}$, and that a further $37 \mathrm{~km}^{2}$ has 'potential' MDAC. This makes the CCS the largest known area of shallow MDAC within the EU SAC network, as mapped using 'good' quality data (i.e. based on survey data; European Environment Agency 2018).

Hollows The plateau is punctuated in several places by areas of deeper water, some of which are isolated from other such areas (Fig. 3). One of the hollows indicated on Fig. 3, for example, is $2 \mathrm{~km}$ across and several metres deeper than the surrounding seabed. Sub-bottom profiles show that these are erosive features, the sub-seabed reflections being truncated by the side walls, which may be quite steep; the hollow crossed by the profile in Fig. 2 cuts $>10 \mathrm{~m}$ of PF sediments. The southwest side of another hollow is formed by a 'cliff' approximately $600 \mathrm{~m}$ long and 6-8 $\mathrm{m}$ high. Sampling and visual inspection of this feature show that it is composed principally of MDAC (see Judd 2005). The sediment type in the floor of these hollows differs from that of the surrounding seabed; in some there are substantial, symmetrical troichoidal sandwaves.

\section{MDAC analyses}

Petrographic analyses Thirty samples of suspected MDAC were collected by mini-Hamon grab sampling. Mineralogical analyses show that 29 of the samples comprise poorlycompacted, quartz-dominated sandstones and siltstones containing various amounts of bioclastic material and cemented by carbonate minerals (Fig. S4a). Some samples have later (modern) encrustations and/or borings by organisms such as bryozoans and serpulids; some show evidence of pre-lithification burrows. The cementing carbonate minerals are high-magnesium calcite, or aragonite or a combination of both. Field et al. (2016a and b) reported several forms of carbonate cements including:

High-Mg-calcite cements:

- early microporous globular, spheroidal aggregates micritic microcrystals (Fig. S4b);

- spheroidal pelloidal aggregates of micritic microcrystals that have coalesced to form a denser matrix (Fig. S4c), some of which may have been reworked and redeposited as faecal pellets;

\section{Aragonite cements:}

- isopachous fringes coating detrital grains (Fig. S4d);

- coarse acicular crystal overgrowths on molluscan shell fragments and pre-existing microcrystalline high-Mg calcite aggregations which have grown into available pore spaces (Fig. S4e).

Where both high-magnesium calcite and aragonite are present, the high-Mg calcite precipitated first (Fig. S4e). The high-Mg calcites typically have a composition ranging for 11 to $48 \mathrm{~mol} \% \mathrm{MgCO}_{3}$. The aragonite is strontium-rich with up to $2 \mathrm{~mol}_{\%} \mathrm{SrCO}_{3}$. Pyrite was observed in many samples, generally as framboids (Fig. S4f) but in some samples as clusters of microcrystals. Iron oxides and oxyhydroxides, in some cases as framboidal pseudomorphs, occur as oxidation products of pyrite. In four samples, there was also cement composed of iron and manganese oxyhydroxides (Fig. S4g); in three cases, this is present within the pore spaces as colloform 


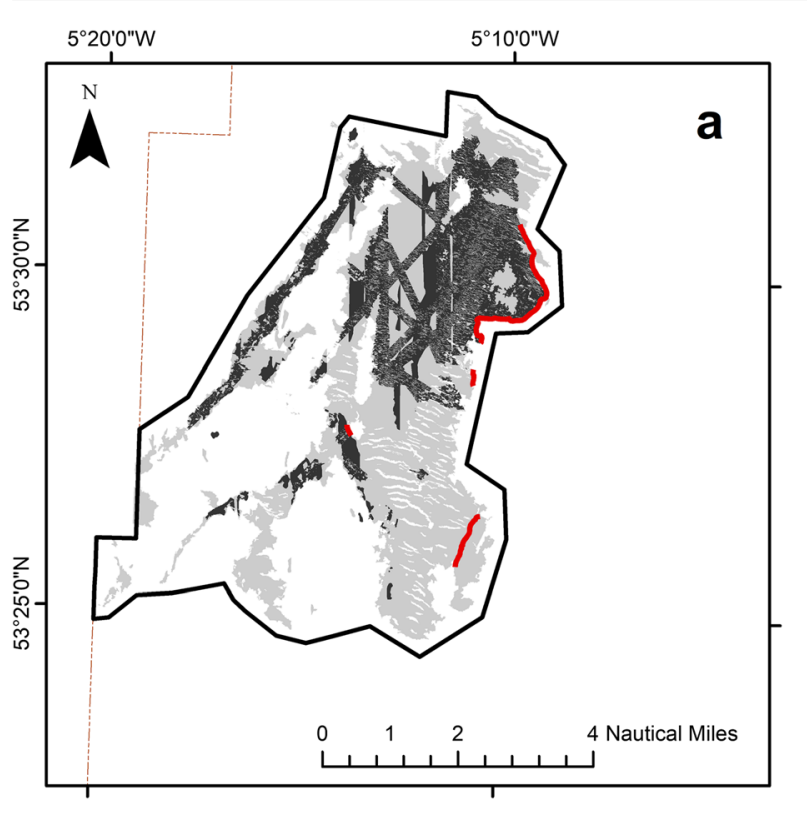

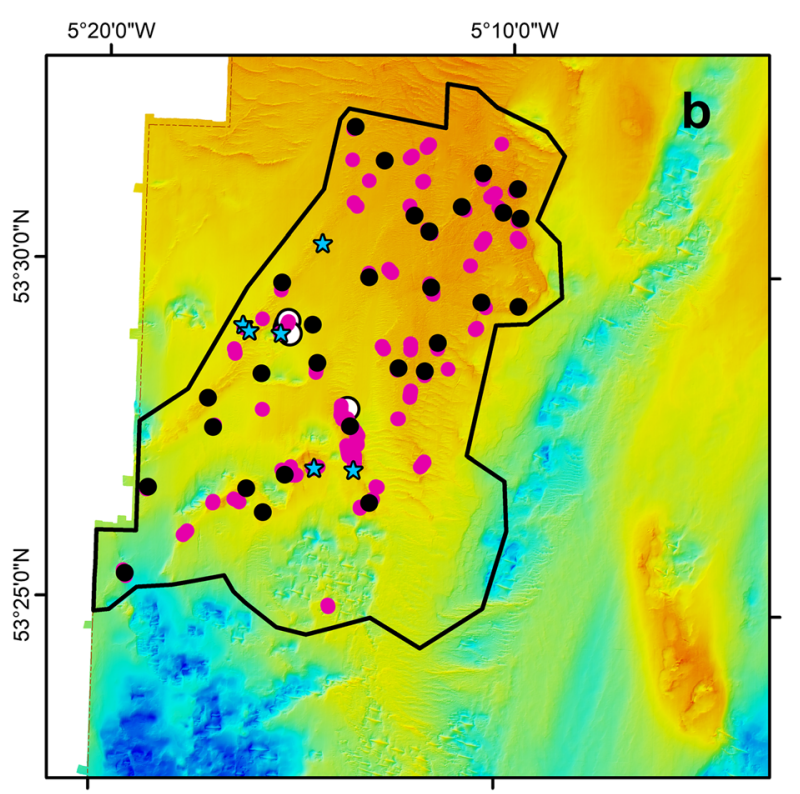

Fig. 4 Distribution of MDAC. a The distribution of MDAC, estimated by combined mapping of all available habitat models based on acoustic (MBES and SSS) data (Duncan 2018). 'High confidence' MDAC and

precipitates (Fig. S4h). In at least one sample, microorganism structures are preserved within an aragonite cement (Fig. S4i).

Carbon and oxygen isotopes The sub-samples of carbonate analysed for carbon and oxygen isotopes included aragonite and high Mg-calcite (individually and mixed), and calcite from modern marine organisms (serpulids, bryozoans and shell material) found on the surface of the samples. Some samples included calcite bioclasts from the original (preMDAC cement) sample. Results are presented in Supplementary Table 1 and Fig. S5. Carbon isotope ratios $\left(\delta^{13} \mathrm{C}\right)$ of the aragonite and high $\mathrm{Mg}$-calcite lie within the range -30 to $-55 \% 0_{\mathrm{vPDB}}$ (see areas $\mathrm{A}$ and $\mathrm{B}$ of Fig. S5,
Legend

MDAC confidence (Duncan, 2018)

High $\left(20 \mathrm{~km}^{2}\right)$

Potential $\left(37 \mathrm{~km}^{2}\right)$

Cliffs

- MDAC samples 2015

- MDAC interpreted from stills 2015 (Noble-James et al., 2017)

is MDAC samples 2008 (Whomersley et al., 2010)

O MDAC samples 2004 (Judd, 2005)

\section{Bathymetry}

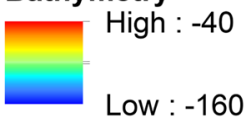

'potential' MDAC cover 20 and $37 \mathrm{~km}^{2}$, respectively of the $116 \mathrm{~km}^{2}$ survey area. b Samples and video evidence

respectively). These are consistent with an authigenic origin in which carbonate precipitation is a consequence of anaerobic methane oxidation (Schoell 1980; Judd and Hovland 2007; Douglas et al. 2017) and comparable to $\delta^{13} \mathrm{C}$ values of MDAC described previously from this site (Judd 2005; Whomersley et al. 2010). $\delta^{13} \mathrm{C}$ values of samples of serpulids, bryozoans and shell material $\left(-1.46\right.$ to $+1.39 \% o_{\mathrm{vPDB}}-$ see Area C of Fig. S5) are consistent with normal marine carbonates. Other values $\left(<-12 \% o_{\mathrm{vPDB}}\right)$, which mainly fall within Area D (Fig. S5) are consistent with a mixture of MDAC minerals and normal marine bioclastic material. Oxygen isotope ratios $\left(\mathrm{O}^{18} / \mathrm{O}^{16}\right)$ indicate the temperature of the porewaters in which carbonate minerals precipitate. If the 
porewater is in equilibrium with the sea water, then it would be expected that its temperature $\left(10.5\right.$ to $11^{\circ} \mathrm{C}$ at CCS $)$ would be reflected by the oxygen isotope ratio; Field et al. (2016b) estimate $\delta^{18} \mathrm{O}$ of 1.1 to $1.2 \% o_{\mathrm{vPDB}}$ for calcite, 1.7 to $1.8 \% o_{\mathrm{vPDB}}$ for aragonite, and 2.5 to $3.5 \% o_{\mathrm{vPDB}}$ for high $\mathrm{Mg}$-calcite. However, the actual range of oxygen isotopes, $\delta^{18} \mathrm{O}-2.78$ to $+4.76 \% \sigma_{\mathrm{vPDB}}$ (see Supplementary Table 1 and Fig. S5), of the carbonate minerals sampled extends beyond the expected range for present day seawater. Even those of the six samples of shell, serpulid and bryozoan material $(+0.86$ to + $2.19 \% o_{\mathrm{vPDB}}$ - see Fig. S5 Area C) extend beyond this range, one sample (a bryozoan) in particular seems to reflect a much colder temperature. The majority of aragonite ratios (Fig. S5 Area A) are higher than the calcite ratios (Fig. S5 Areas C and D), and the majority of high Mg-calcite ratios (Fig. S5 Area B) are higher again; each of these ranges is more or less centred on the expected range of values. Indeed, the majority of the high $\mathrm{Mg}$-calcite ratios lie within the predicted range. However, a significant number lie outwith the predicted ranges, suggesting that the porewater in which they precipitated was influenced by water of a different composition to seawater, and/or temperature conditions varied from those of the present day. Enrichment of porewater by ${ }^{18} \mathrm{O}$ may be caused by waters rising from the gas source (O'Reilly et al. 2014), or from dissociating gas hydrates (Crémière et al. 2016).

Strontium isotopes Strontium isotope ratios $\left({ }^{87} \mathrm{Sr} /{ }^{86} \mathrm{Sr}\right)$ of samples are expected to reflect those of the seawater or pore fluid with which they are in equilibrium. According to Mokadem et al. (2015) modern seawater has a ${ }^{87} \mathrm{Sr} /{ }^{86} \mathrm{Sr}$ ratio of $0.709179 \pm 0.000002$. Variations from this ratio may occur, for example, when the sample material has precipitated from pore water not in equilibrium with seawater, or when the ambient seawater at the time of precipitation was dissimilar to that of the present day. However, it seems that, despite a general trend of increasing ${ }^{87} \mathrm{Sr} /{ }^{86} \mathrm{Sr}$ over the last $2.5 \mathrm{Ma}$, there has been no discernable variation over Quaternary glacial-interglacial cycles (Mokadem et al. 2015). Any difference between the samples ${ }^{87} \mathrm{Sr} /{ }^{86} \mathrm{Sr}$ and that of modern seawater can therefore be attributed to porewaters being in disequilibrium with seawater. Fourteen ${ }^{87} \mathrm{Sr} /{ }^{86} \mathrm{Sr}$ analyses were undertaken (Field et al. 2017): five of a seawater standard, four of shell material from organisms encrusting the samples, and five of pure aragonite micro-drilled from carbonate cements (Supplementary Table 2). The seawater standards' Sr ratios all correspond to modern seawater, within the limits of experimental error, as does one of the shell fragments (GT 025-2). However, the remaining samples have higher ratios, the highest (GT120) being 0.709221 $( \pm 0.000005)$. This suggests the input of a small component of radiogenic $\mathrm{Sr}$, presumably from porewaters accompanying the methane during its rise from depth, although glacial weathering cannot be ruled out. However, all the values fall within the range of ${ }^{87} \mathrm{Sr} /{ }^{86} \mathrm{Sr}$ for present-day seawater suggested by Elderfield (1986).

Uranium-thorium isotopes - age dating U-Th dating was conducted on carbonate extracted from nine samples (Field et al. 2017). Material from the majority of the aragonite and all micritic high-Mg calcite samples/sub-samples displayed evidence of the loss of soluble $U$ through leaching, precluding the calculation of reliable dates. However, a total of five subsamples of aragonite obtained from samples GT106 and GT141 each provided single dates, and a further two dates were derived for two pairs of aragonite sub-samples from samples GT120 and GT141 (see Supplementary Table 3). These suggest that aragonite precipitation occurred between approximately $17,000( \pm 5500)$ to $4000( \pm 200)$ years BP.

Epibenthic fauna and sediment meiofauna The surficial sediments and exposed Quaternary sediments were found generally to support, at best, a very sparse epifauna. In contrast, areas of MDAC support a diverse range of soft corals, sponges, tubeworms, anemones, scour-resistant hydroids and bryozoans (Fig. S6), with a high abundance of erect filter feeders. Noble-James et al. (2019) identified five taxa that are substantially more abundant on exposed MDAC than elsewhere. These are the soft coral Alcyonium digitatum, the hydroid genera Nemertesia (including Nemertesia antennina and Nemertesia ramosa) and Tubularia (including Tubularia indivisa), the branching bryozoan genus Cellaria and the tube-building polychaete family Sabellidae. The low-relief MDAC was characterized by the same overall epifaunal assemblage; however, most of the taxa, particularly A. digitatum and Tubularia, were significantly more abundant on the highrelief MDAC. The presence of this epifaunal assemblage is dependent on the availability of the hard substrate provided by MDAC. Indeed, the identification of MDAC on video and stills images is aided by the presence of the epifauna. Where a thin veneer of surficial sediment covers this hard substrate this epifauna is the only visual evidence of the MDAC.

The nematode populations of seven samples of seabed sediment were investigated (Physalia 2016). A total of 145 distinct nematode taxa were identified. This remarkable diversity might be explained by the heterogeneity of microhabitats provided by the combination of sediment matrix and carbonate cements.

Evidence of gas seepage Apart from the presence of seismic indications of gas beneath, and MDAC on the seabed, evidence of active gas seepage was provided by the following indicators from video transects: bubbles seen rising from the seabed (Fig. S7a); evidence of AOM (black patches in the seabed sediment consistent with the presence of $\mathrm{H}_{2} \mathrm{~S}-$ Fig. $\mathrm{S} 7 \mathrm{~b}$ ); white patches on the rims of some MDAC exposures 
consistent in appearance with bacterial mats, for example sulphide oxidizing Beggiatoa spp. (Fig. S7c). Water column targets on SSS are indicative of rising bubble plumes (Fig. S7d); similar targets on ES were more numerous, but their interpretation is less certain. None of these seepage indicators were widespread (Fig. S7e).

Methane in the water column METS data from the camera drop-frame indicate methane concentrations in bottom waters ranging from 1.2 to $21.4 \mathrm{nmol}^{-1}$ (Fig. S8); the highest concentrations were recorded at locations where bubbles were seen rising from the seabed (Fig. S7e). The validity of these results is suggested by comparison with the methane concentrations in the sea bottom water samples (3.56 to $7.66 \mathrm{nmoll}^{-1}$; see Fig. S1d for locations). Methane concentrations in midwater and near surface waters within CCS (3.06 to 5.78 and 3.74 to $5.80 \mathrm{nmol}^{-1}$, respectively), and in the deep water channel control site (2.00 and $4.41 \mathrm{nmol} \mathrm{l}^{-1}$, respectively) were also significantly above the 'background' concentrations of the southern control site $\left(0.21\right.$ and $0.08 \mathrm{nmol}^{-1}$, respectively).

\section{Discussion}

Geological implications It has been demonstrated that gas (methane) rises to and through the seabed more or less throughout the CCS site. It is assumed that this comes from underlying coal-bearing Westphalian rocks (Croker 1995; Judd et al. 2007) that underlie the site and have probably been producing gas for many millions of years. They extend beyond this site and the structural deformation, as indicated by features such as the Quadrant 109 Syncline and faulting, likely provided migration pathways as they did along the Codling fault and at the Kish Bank seep mounds. Wingfield et al. (1990) showed that acoustic turbidity (AT), a strong seismic indicator of shallow gas, also extends beyond the site (see Fig. 1) suggesting the potential for more MDAC occurrences yet to be discovered in this area. Indeed, two locations outwith the CCS boundary have the appearance on MBES of MDAC (Fig. 3) but have not been investigated. The sediments above the AT, and in the few places where AT is absent, are ascribed (Wingfield et al. 1990; Jackson et al. 1995; and Mellett et al. 2015) to the Prograded Facies (PF) of the Western Irish Sea Formation (late-Weichselian), and the unconformably overlying Wave and Bank Facies of the Surface Sands Formation (Holocene). These sediments are described as lying directly on the eroded surface of the Westphalian, at least over the majority of the site. However, this unconformity is either obscured by the AT, or lies beneath the depth of penetration of the SBP. Possible examples of the UT member presumably represent the Weichselian glaciation, and underlie the PF.
During the Last Glacial Maximum (LGM) ( $26 \mathrm{ka})$ ice cover of the Irish Sea was complete; the Irish Sea Ice Stream (ISIS) extended southwards beyond the Scilly Isles (Smedley et al. 2017; Scourse et al. 2019). As there is no reason to suppose that the emanation of Westphalian gas was interrupted by surface conditions during the glacial period, it is assumed that gas accumulated beneath the ice, possibly as gas hydrates formed as a result of increased pressures associated with ice loading. The presence of gas hydrates during the LGM has been proposed for the North Sea (Fichler et al. 2005), the Barents Sea (Crémière et al. 2016) and offshore Svalbard (Portnov et al. 2016); these last authors speculated that gas hydrates were widespread beneath ice-covered continental margins of the Northern Hemisphere during the LGM. Mazzini et al. (2017) argued that it was the dissociation of gas hydrates during post-glacial (post-Younger Dryas) warming in the Norwegian North Sea that triggered the gas escape that resulted in pockmark formation and the precipitation of MDAC in them. ISIS subsequently retreated northward, the ice front reaching the CCS area about 21.9 to $20.7 \mathrm{ka}$, before retreating more rapidly across the Northern Irish Sea basin (Clark et al. 2010; Chiverrell et al. 2013). Iceberg scour marks, eskers and De Geer moraines to the northeast of the CCS site are evidence that the decaying ice sheet terminated in a proglacial water body approximately $18 \mathrm{ka}$; however, it is unclear whether this was marine or lacustrine (Van Landeghem et al. 2009). The PF sediments were deposited, probably rapidly, during the northward retreat of ISIS. Much of the PF material was probably derived from the Welsh mountains (which became ice-free by $16 \mathrm{ka}$; Clark et al. 2010), as suggested by their progradation from coarser in the SE to finer in the Western Mud Belt to the NW (Jackson et al. 1995), and the character of dropstones collected during this study. As MDAC is cementing PF sediments, its formation must have post-dated it. This implies that at least some PF sediments were deposited before $\sim 17 \mathrm{ka}$ (the oldest U-Th date acquired during this study). Evidently, the period was one of significant environmental change with the coastline retreating with sea level rise. The connection northwards to the Malin Sea was blocked until the separation of the Scottish and Irish ice after $16.5 \mathrm{ka}$ (Finlayson et al. 2014). As $\mathrm{SO}_{4}{ }^{2-}$, an essential prerequisite for the formation of MDAC by AOM, is far more highly concentrated in seawater than freshwater, MDAC may be an indicator that seawater had reached CCS by $\sim 17 \mathrm{ka}$. Once the North Channel was opened the hydrographic setting of the CCS site evolved rapidly. Jackson et al. (1995) attributed the erosion surface between the PF and the SSF to the earlyHolocene marine transgression $(\sim 10.2 \mathrm{ka})$; this limits the timing of deposition of the PF to the period between $\sim 20$ and $\sim 10 \mathrm{ka}$. The SSF deposits and the mobile sediments are presumed to have been derived from eroded PF sediments. Erosion of the PF sediments has produced the deep-water channel to the east of CCS and the hollows within the plateau, 
exposing a gross vertical section of $30 \mathrm{~m}$ (see Figs. 2 and S2), and individual exposures of $15 \mathrm{~m}$ in the sidewalls of hollows and the 'cliffs' in the NE area of CCS. Once ISIS retreated from CCS accumulated gas was able to escape. Presumably, this escape was initially rapid, possibly explosive, as postulated for the formation of the Scanner pockmark in the North Sea (Judd et al. 1994). Was this gas escape implicated in the initiation of erosion of the PF sediments in and east of CCS? A more complete understanding of the glacial/post-glacial history of this site would require a targeted (visually guided) sampling programme, and/or coring/drilling through the stratigraphic sequence.

U-Th dates in this study, indicating that MDAC formation continued during the period $\sim 17$ to $\sim 5 \mathrm{ka}$, and evidence of present-day gas seepage (bubbles in the water column, possible sulphidic sediments, and possible Beggiatoa mats) suggest that anaerobic methane oxidation and MDAC formation continues to the present day. Analysis of MBES, visual and petrographic data shows that MDAC has formed over a considerable area (see Fig. 4a and b). Considerable thicknesses of MDAC have formed; $\sim 6 \mathrm{~m}$ in the near-vertical MDAC 'cliff' (point $\mathrm{C}$ in Fig. 3), and similar thicknesses in the 'cliffs' marking the eastern boundary of the CCS plateau (Fig. 3). The formation of these thicknesses of MDAC within a period of $\sim 17$ ka suggests a considerably faster MDAC formation rate than the $1.1 \mathrm{~cm} \mathrm{ka}^{-1}$ suggested by Bayon et al. (2009) for a $5.5 \mathrm{~cm}$ thick MDAC slab recovered from the Nile Fan. However, because the CCS samples from this and previous studies have all been collected by 'blind' grab sampling it is impossible to draw any conclusions about the MDAC stratigraphy. A systematic top to bottom sampling by ROV of one of the cliffs, or vertical coring, is required for this to be established.

The combination of high-Mg calcite and aragonite with associated pyrite is typical of MDAC cements reported from other locations, and is considered diagnostic of the anaerobic oxidation of methane (Jørgensen 1992; Judd and Hovland 2007). In the MDAC samples described in this study, high$\mathrm{Mg}$ calcite precipitated before aragonite. This is true, for example, for all three samples for which U-Th age dates have been acquired. So, in each case, irrespective of the age of the aragonite, high-Mg calcite precipitated first; the precipitation order does not mean that there was a time period during which one mineral species formed across CCS, followed by a period characterized by the other. The change from high-Mg calcite to aragonite implies a change of conditions during the periods of MDAC formation (Sauer et al. 2017), but the significance of the domination of one carbonate mineral over another is unclear. This may be a function of the availability of sulphate (from seawater) or the methane flux rate. Crémière et al. (2016) suggested that dominant high-Mg calcite occurred when high rates of AOM activity could be sustained by the methane flux. However, Magalhães et al. (2012) considered that high-Mg calcite formed when there was focussed methane flow, whereas aragonite formed when the flow was more diffuse. Hovland (2002) suggested that open migration pathways would progressively become blocked as carbonate minerals precipitated, causing the rising methane to find alternative routes towards the seabed and restricting the flow of $\mathrm{SO}_{4}$ from the seawater. Progressively, in the absence of open pathways, methane and $\mathrm{SO}_{4}$ must diffuse more slowly by permeable flow through bulk sediment, and eventually all pathways are sealed causing a more major change to the seabed plumbing system. In CCS it is suggested that high-Mg calcite formed first where there was a plumbing system that allowed methane to flow through open pathways. Then, as these pathways became choked, methane diffused more slowly through the remaining pore spaces where aragonite formed.

The extensive hard grounds mapped across the site are conclusively identified as MDAC, and the observed white bacterial mats and black sediment patches are consistent with $\mathrm{AOM}$, and therefore the on-going formation of MDAC beneath the seabed at the SMTZ. However, the extensive seabed occurrences of MDAC, and in particular the MDAC 'cliffs', indicate that it has been exposed by seabed erosion. Under present hydrodynamic conditions erosion continues, as is evidenced by the small fragments of MDAC observed on the seabed near MDAC exposures. The exposed extent of MDAC is therefore in a state of continual flux, with thin shifting surficial sediment veneers uncovering and burying MDAC across the cSAC/SCI at various temporal and spatial scales. It is thought likely that the hard MDAC substrate will persist beneath these veneers, unless erosion has been substantial, thus retaining the potential for exposure (and colonization by fauna) at a future point. It is possible that deeply buried areas that are not currently delineated as MDAC at or near the seabed (e.g. the possible MDAC cliff in the south east of the survey area) could become exposed if a significant hydrodynamic event or regime change occurs in the future.

Ecological implications There is a marked contrast between the epibenthic fauna colonizing the MDAC and that of the surrounding seabed. It should however be noted that these taxa are common on hard rocky substrates in UK waters. Although they are clearly associated with MDAC within CCS, they are not exclusive to this habitat, and are not indicative of chemotrophic associations. Examination of epifaunal, macrofaunal and meiofaunal taxon lists from the 2015 survey provided no evidence of chemosynthetic (methanotrophic or thiotrophic) fauna associated with methane seepage. Two Desmodorid nematode genera, Leptonemella and Catonema, exhibit relationships with endosymbiotic cyanobacteria. Whereas the presence of sulphidic conditions may be suitable for these organisms, the samples in which they were found could not be directly linked to any evidence of gas seepage (Physalia 2016). Seep specialists have been reported from 
continental shelf sites elsewhere; for example, the bivalve Thyasira sarsi and the pogonophore Siboglinum poseidoni at the Scanner pockmark, North Sea (Dando and Austen 1991). However, they are found only within a few centimetres of the seeps. Although sulphidic sediments in which such seep specialists might be found were observed during video transects, none were sampled. To target such sediments, it may be necessary to use a sampling system capable of being guided visually (e.g. a Remotely Operated Vehicle).

Atmospheric implications Observations of gas bubbling from the seabed, and the high methane concentrations in the water, indicate active methane gas seepage. The methane concentrations in the sea bottom waters ( 1.2 to $21.4 \mathrm{nmol} \mathrm{l}^{-1}$ ) are comparable to those reported from this site by Judd $(2005 ; 2.4$ to $3.0 \mathrm{nmol} \mathrm{l}^{-1}$ ) and by Van Landeghem et al. (2015; 4.3 to $5.4 \mathrm{nmol} \mathrm{l}^{-1}$ ). These concentrations are also comparable to that of the control station within the channel east of CCS $\left(1.27 \mathrm{nmol} \mathrm{l}^{-1}\right)$, which lies within the area of shallow gas (according to Wingfield et al. 1990, and Mellett et al. 2015, and this study). However, they are relatively low when compared to those of bottom waters in seepage areas in similar water depths elsewhere: 15-300 nmol $1^{-1}$ at Tommeliten seep in the North Sea (Schneider von Deimling et al. 2011); 40 to $1628 \mathrm{nmol} \mathrm{l}^{-1}$ at a seep site south of the Dogger Bank, North Sea (Mau et al. 2015). At the control site, 4 nautical miles $(7.4 \mathrm{~km})$ south of CCS, which is outwith both the shallow gas area and the sub-crop of the coal-bearing Westphalian, the concentration is only $0.25 \mathrm{nmol} \mathrm{l}^{-1}$. This is taken to represent the 'background' concentration.

The methane from CCS is likely to be transported beyond the study area by the strong tidal currents. Water-borne methane is subject to oxidation, a process that is mediated by microbes (Schmale et al. 2015). So, the methane originating from the CCS seabed is able to enter the food chain. However, where the methane concentration exceeds that of the overlying atmosphere, normal gas exchange processes will result in the export of methane to the atmosphere. Van Landeghem et al. (2015) considered that concentrations in excess of $3 \mathrm{nmol}^{-1}$ are saturated in methane relative to the overlying atmosphere. Whereas the majority (98\%) of CCS seabed concentrations exceed $3 \mathrm{nmol}^{-1}$, sea surface concentrations are expected to be significantly lower, as is the case at the two North Sea sites mentioned above. However, concentrations in all three near-surface samples exceed $3 \mathrm{nmol}^{-1}$ (3.74 to $5.80 \mathrm{nmoll}^{-1}$ ), as does the deep-water channel sample $\left(4.41 \mathrm{nmol} \mathrm{l}^{-1}\right)$, and one of the four samples reported from the area by Judd $2005\left(3.5 \mathrm{nmol} \mathrm{l}^{-1}\right)$. This suggests that CCS exports methane to the atmosphere. This assumption could be tested in future surveys by the deployment of equipment to measure the methane concentration of the near-sea surface air, as has been done in the North Sea by Judd (2015) and Schneider von Deimling et al. (2015).
The most significant impact of this site on atmospheric methane concentrations probably occurred when the site became free of ice, 21.9 to $20.7 \mathrm{ka} \mathrm{BP}$. At this time, gas that had accumulated beneath the ice, possibly sequestered in gas hydrates, was released, providing positive feedback to the global warming following the LGM.

\section{Conclusions}

Methane, probably derived from underlying coal-bearing Westphalian strata, has been rising to the seabed within the CCS area for a considerable period of time, although it was unable to reach the surface when there was ice cover. After the LGM, the site became free of ice about $\sim 21 \mathrm{ka}$ BP. Once sea-level rise brought seawater to the site making $\mathrm{SO}_{4}{ }^{2-}$ available, $\mathrm{AOM}$ was possible and MDAC formation began. This is demonstrated by MDAC formation which has continued since $17 \mathrm{ka}$ BP producing an enormous quantity of MDAC; it covers an area of $20 \mathrm{~km}^{2}$ (possibly $57 \mathrm{~km}^{2}$ ), and is in places $6 \mathrm{~m}$ thick. This is the largest known area of shallow MDAC in the EU MPA network (as mapped using survey data).

Since the deposition of the post-glacial sediments, an erosive regime, which probably started with the Holocene transgression (10.2 ka BP), has resulted in the cutting of a deepwater channel to the east of CCS and several hollows within the plateau the site occupies. This has exposed gross vertical sections of PF sediments and the extensive MDAC, including some cliff-like exposures (one of which is $>500 \mathrm{~m}$ long and about $6 \mathrm{~m}$ high).

Gas bubbles and evidence (sulphidic sediments and bacterial mats) consistent with active AOM observed during this survey witness the continued gas escape, as do the anomalously high concentrations of methane in the water column. It is probable that methane is exported from CCS by the strong tidal currents, some being oxidized and some escaping to the atmosphere.

The MDAC has been colonized by a variety of organisms that favour a hard substrate. This epibenthic fauna contrasts markedly with that of the other seabed types in this area, providing evidence to support the designation and management of this habitat as a resource of conservation importance.

This site provides ideal opportunities for the understanding of the significance of long periods of methane escape from an underlying source for sediment deposition and erosion, MDAC formation, benthic communities, and the fate of methane in the water and atmosphere. However, to realize the site's potential, further studies would require the deployment of various types of equipment not available to this study. 
Acknowledgements We would like to thank the following for their contributions to this project. The scientists and crew of the RV Cefas Endeavour, who conducted the CEND23/15 survey at the Croker Carbonate Slabs MPA. Colleagues at JNCC contributed to the planning and organization of the cruise, and the post-cruise data analyses, whilst colleagues at Cefas processed PSA samples, coordinated analyses of fauna and video/stills, and compiled results. The British Geological Survey conducted analysis and dating of MDAC samples and provided sample images. Imagery analysis was conducted by Seastar Survey Limited, meiofaunal identification by Physalia Limited, and macrofaunal identification by Thomson Ecology and the Institute of Estuarine and Coastal Studies. Seawater methane was analysed by Rob Upstill-Goddard at Newcastle University. Riccardo Arosio, Jerry Dickens, Katrien Van Landeghem and an anonymous reviewer made helpful comments on the text.

Funding information This project was funded by the Department for Environment, Food and Rural Affairs (Defra) under contract MB0129.

Open Access This article is distributed under the terms of the Creative Commons Attribution 4.0 International License (http:// creativecommons.org/licenses/by/4.0/), which permits unrestricted use, distribution, and reproduction in any medium, provided you give appropriate credit to the original author(s) and the source, provide a link to the Creative Commons license, and indicate if changes were made.

\section{References}

Aloisi G, Bouloubassi I, Heijs SK, Pancost RD, Pierre C, Sinninghe Damste JS, Gottscal JC, Forney LJ, Rouchy J-M (2002) CH4consuming microorganisms and the formation of carbonate crusts at cold seeps. Earth Planet Sci Lett 203:195-203

Andrews JE (1988) Methane-related Mg-calcite cements in recent tidal flat sediments from the Firth of Forth. Scott J Geol 24:233-244

Bayon G, Henderson GM, Bohn M (2009) U-Th stratigraphy of a cold seep carbonate crust. Chem Geol 260:47-56. https://doi.org/10. 1016/j.chemgeo.2008.11.020

Boetius A, Wenzhöfer F (2013) Seafloor oxygen consumption fuelled by methane from cold seeps. Nat Geosci 6:725-734

Boetius A, Ravenschlag K, Schubert CJ, Rickert D, Widdel F, Gieseke A, Amann R, Jørgensen BB, Witte U, Pfannkuche O (2000) A marine microbial consortium apparently mediating anaerobic oxidation of methane. Nature 407:623-626

British Geological Survey (1994) East Irish Sea (special sheet edition) 1: 250,000. Edinburgh, Scotland

British Geological Survey: Geoindex Offshore (n.d.). http://mapapps2. bgs.ac.uk/geoindex_offshore. Accessed 28 February 2019

Callaway A, Bolam S, Diesing M, Stephens D, Murray J (2015) North St. George's channel rMCZ post-survey site report. Report to the Department of Environment, Food and Rural Affairs. No. 4. Centre for Environment, fisheries and aquaculture science (Cefas), Lowestoft, UK

Chiverrell RC, Thrasher IM, Thomas GSP, Lang A, Scourse JD, Van Landeghem KJJ, McCarroll D, Clark CD, O'Cofaigh CÓ, Evans DJA, Ballantyne CK (2013) Bayesian modelling the retreat of the Irish Sea ice stream. J Quat Sci doi 28:200-209. https://doi.org/10. 1002/jqs.2616

Clark CD, Hughes ALC, Greenwood SL, Jordan C, Sejrup HP (2010) Pattern and timing of retreat of the last British-Irish Ice Sheet. Quat Sci Rev doi.org/https://doi.org/10.1016/j.quascirev.2010.07.019
Crémière A, Lepland A, Chand S, Sahy D, Condon DJ, Noble SR, Martma T, Thornsnes T, Sauer S, Brunstad H (2016) Timescales of methane seepage on the Norwegian margin following collapse of the Scandinavian Ice Sheet. Nature Comms 7. https://doi.org/10. 1038/ncomms 11509

Croker PF (1995) Shallow gas accumulation and migration in the western Irish Sea. In: Croker PF, Shannon PM (eds) The petroleum geology of Ireland's offshore basins. Geol Soc London Sp Publ 93:41-58

Croker PF, Kozachenko M, Wheeler AJ (2005) Gas-related seabed structures in the Western Irish Sea (IRL-SEA6). January 2005 Tech. Rep. Strategic Environmental Assessment of the Irish Sea (SEA6), UK Department of Trade and Industry

Dando P (2010) Biological communities at marine shallow-water vent and seep sites. In: Kiel S (ed) The vent and seep biota - from microbes to ecosystems, Topics in Geomicrobiology Vol, vol 33. Springer, Dordrecht, pp 333-378

Dando PR, Austen MC, Burke RA Jr, Kendall MA, Kennicutt MC II, Judd AG, Moore DC, O'Hara SCM, Schmaljohann R, Southward AJ (1991) Ecology of a North Sea pockmark with an active methane seep. Mar Ecol Prog Ser 70:49-63

Douglas PMJ, Stolper DA, Eiler JM, Sessions AL, Lawson M, Shuai Y, Bishop A, Podlaha OG, Ferreira AA, Santos Neto EV, Niemann M, Steen AS, Huang L, Chimiak L, Valentine DL, Fiebig J, Luhmann AJ, Seyfried WE Jr, Etiope G, Schoell M, Inskeep WP, Moran JJ, Kitchen N (2017) Methane clumped isotopes: progress and potential for a new isotopic tracer. Org Geochem. https://doi.org/10.1016/j. orggeochem.2017.07.016

Duncan G (2018) Method for creating a composite map of annex I submarine structures made by leaking gases for Croker carbonate slabs cSAC/SCI. No. JNCC report no. 611. JNCC, Peterborough

Elderfield H (1986) Strontium isotope stratigraphy. Palaeogeogr Palaeoclimatol Palaeoecol 57:71-90

European Environment Agency (2018). Submarine structures made by leaking gases. https://eunis.eea.europa.eu/habitats/10010\#sites, European Commission, Brussels. Accessed 28 Feb 2019

Fichler C, Henriksen S, Rueslaatten H, Hovland M (2005) North Sea Quaternary morphology from seismic and magnetic data: indications for gas hydrates during glaciation? Pet Geosci 11:331-337

Field LP, Milodowski AE, Wagner D, Sloane H, Leng MJ, Marriott AL (2016a) Mineralogy, petrography and stable isotope study of methane-derived authigenic carbonates (MDAC) from the Croker Carbonate Slab, CEND 23/25 Survey Part 1. British Geological Survey Commissioned Report, CR/16/164. $121 \mathrm{p}$

Field LP, Milodowski AE, Wagner D, Sloane H, Leng M,.Marriott AL (2016b) Mineralogy, petrography and stable isotope study of methane-derived authigenic carbonates (MDAC) from the Croker Carbonate Slab, CEND 23/25 Survey Part 2. British Geological Survey Commissioned Report, CR/16/164. 149 p

Field LP, Sahy D, Millar I, Milodowski AE (2017) Analysis of methanederived authigenic carbonates (MDAC) from the Croker Carbonate Slab CEND 23/25 Survey. Stage 2 Radiometric dating. British Geological Survey Commissioned Report, CR/17/028. $27 \mathrm{p}$

Finlayson A, Fabel D, Bradwell T, Sugden D (2014) Growth and decay of a marine terminating sector of the last British Irish Ice Sheet. Quat Sci Rev 83:28-45

Gafeira J, Long D (2015a) Geological investigation of pockmarks in the Scanner Pockmark SCI. JNCC report no 570. JNCC, Peterborough, UK

Gafeira J, Long D (2015b) Geological investigation of pockmarks in the Braemar Pockmarks SCI and surrounding area. JNCC report no 571. JNCC, Peterborough, UK 
Holmes R, Tappin DR (2005) DTI Strategic Environmental Assessment Area 6, Irish Sea, seabed and surficial geology and processes. British Geological Survey Commissioned Report, CR/05/057

Hovland M (2002) On the self-sealing nature of marine seeps. Cont Shelf Res 22:2387-2394

Hovland M, Talbot MR, Qvale H, Olaussen S, Aasberg L (1987) Methane-related carbonate cements in pockmarks of the North Sea. J Sed Pet 57:881-892

IGS and GSI (Institute of Geological Sciences and Geological Survey of Ireland) (1982) Anglesey Sheet $53^{\circ} \mathrm{N}-06 \mathrm{~W} 1: 250,000$ Solid Geology

Jackson DI, Jackson AA, Evans D, Wingfield RTR, Barnes RP, Arthur MJ (1995) The geology of the Irish Sea. BGS UK offshore regional rep. HMSO, London

Jørgensen NO (1992) Methane-derived carbonate cementation of marine sediment from the Kattegat, Denmark. Geochemical and geological evidence. Mar Geol 88:71-81

Judd AG (2005) The distribution and extent of methane-derived authigenic carbonate. Technical report, strategic environmental assessment of the Irish SEA (SEA6). UK Department of Trade and Industry, London

Judd AG (2015) The significance of the 22/4b blow-out site methane emissions in the context of the North Sea. Mar Pet Geol 68(b): 836-847

Judd AG, Hovland M (2007) Seabed fluid flow: impact of geology, biology and the marine environment. Cambridge University Press, Cambridge

Judd A, Long D and Sankey M (1994) Pockmark formation and activity, UK block 15/25, North Sea. Bulletin, Geological Society of Denmark 41:34-49

Judd AG, Sim R, Kingston P, McNally J (2002) Gas seepage on an intertidal site: Torry Bay, Firth of Forth, Scotland. Cont Shelf Res 22:2317-2331

Judd A, Croker P, Tizzard L, Voisey C (2007) Extensive methane-derived authigenic carbonates in the Irish Sea. Geo-Mar Lett 27:259-267

Levin LA, Baco AR, Bowden DA, Colaco A, Cordes EE, Cunha MR, Demopoulos AWJ, Gobi J, Grupe BM, Le J, Metaxas A, Netburn AN, Rouse GW, Thurber AR, Tunnicliffe V, Van Dover CL, Vanreusel A, Watling L (2016) Hydrothermal vents and methane seeps: rethinking the sphere of influence. Front Mar Sci. https:// doi.org/10.3389/fmars.2016.00072

Magalhães VH, Pinheiro M, Ivanov MK, Kozlova E, Blinova V, Kolganova J, Vasconcelos C, McKenzie JA, Bernasconi, SM, Kopf A, Diaz del Rio V, González J, Somoza L (2012) Formation processes of methane-derived authigenic carbonates from the Gulf of Cadiz. Sed Geol. https://doi.org/10.1016/j.sedgeo.2011.10.013

Mau S, Gentz T, Körber J-H, Torres M, Römer M, Shaling H, Winterstellar P, Martinez R, Schlüter M, Helmke E (2015) Seasonal methane accumulation and release from a gas emission site in the Central North Sea. Biogeosci 12:5261-5276

Mazzini A, Svensen HH, Forsberg CF, Linge H, Lauritzen S-E, Haflidason H, Hammer Ø, Planke S, Tjelte TI (2017) A climatic trigger for the giant Troll pockmark field in the northern North Sea. Earth Planet Sci Lett 464:24-34

Mellett C, Long D, Carter G, Chiverrell G, van Landeghem K (2015) Geology of the seabed and shallow subsurface: the Irish Sea. British Geological Survey Commissioned Report, CR/15/057. 52 pp

Mokadem F, Parkinson IJ, Hathorne EC, Anand P, Allen JT, Burton KW (2015) High-precision radiogenic strontium isotope measurements of the modern and glacial ocean: limits on glacial-interglacial variations in continental weathering. Earth Planet Sci Lett 415:111-120

Niemann H, Elvert M, Hovland M, Orcutt B, Judd A, Suck I, Gutt J, Joye S, Damm E, Finster K, Boetius A (2005) Methane emission and consumption at a North Sea gas seep (Tommeliten area). Biogeosci 2:335-351

Noble-James T, Clare D, Diesing M, Eggett A, Judd A, Silburn B, Kröger $\mathrm{K}$ (2017) Croker carbonate slabs cSAC/SCI initial monitoring report. JNCC/Cefas partnership report no. 17. JNCC, Peterborough, UK

Noble-James T, Judd A, Diesing M, Clare D, Eggett A, Silburn B, Duncan G (2019) monitoring shallow methane-derived authigenic carbonates: insights from a UK marine protected area. Accepted for publication in Aquatic Conservation: Mar \& Freshwater Ecosystems, Feb 2019. (in review)

NPWS (2015) Codling Fault Zone SAC Site Synopsis. Republic of Ireland, National Parks \& Wildlife Service

O'Reilly SS, Hryniewicz K, Little CTS, Monteys X, Szpak MT, Murphy BT, Jordan SF, Allen CCR, Kelleher BP (2014) Shallow water methane-derived authigenic carbonate mounds at the Codling Fault Zone, western Irish Sea. Mar Geol. https://doi.org/10.1016/j. margeo.2014.08.007

Physalia, 2016. Taxonomic analysis of Meiofaunal nematode samples collected from benthic sediments from the Croker carbonate slabs SCI. Physalia Applied Sciences, Harpenden, UK., 26p

Portnov A, Vadakkepuliyambatta S, Mienert J, Hubbard A (2016) Icesheet driven methane storage and release in the Arctic. Nat Comms $7: 10314$

Salisbury RSK (1990) Shallow gas reservoirs and migration paths over a Central North Sea diapir. In: Ardus DA, Green CD (Eds) Safety in offshore drilling: the role of shallow gas surveys, Kluwer, Dordrecht, pp167-180

Sauer S, Crémière A, Knies J, Lepland A, Sahy D, Martma T, Noble SR, Schönenberger J, Klug M, Schubert CJ (2017) U-TH chronology and formation controls of methane-derived authigenic carbonates from the Hola trough seep area, northern Norway. Chem Geol 470:64-179

Schmale O, Leifer I, Schneider von Deimling J, Stolle C, Krause S, Kießlich K, Frahm A, Treude T (2015) Bubble transport mechanism: indications for a gas bubble-mediated inoculation of benthic methanotrophs into the water column. Cont Shelf Res 103:70-78. https://doi.org/10.1016/j.csr.2015.04.022

Schneider von Deimling J, Rehder G, Greinert J, McGinnis DF, Boetius A, Linke P (2011) Quantification of seep-related methane gas emissions at Tommeliten, North Sea. Cont Shelf Res 31:867-878

Schneider von Deimling J, Linke P, Schmidt M, Rehder G (2015) Investigations of the geologic, water-column, and atmospheric phenomena of a persistent North Sea gas blowout. Mar Pet Geol 68(b): $718-730$

Schoell M (1980) The hydrogen and carbon isotopic composition of methane from natural gases of various origins. Geochim Cosmochim Acta 44:649-661

Scourse J, Saher M, Van Landegham KJJ, Lockhart E, Purcell C, Gallard L, Roseby Z, Allinson B, Pieńkowski AJ, O'Cofaigh C, Praeg D, Ward S, Chiverrell R, Moreton S, Fabe D, Clark CD (2019) Advance and retreat of the marine-terminating Irish Sea Ice Stream into the Celtic Sea during the Last Glacial: timing and maximum extent. Mar Geol. https://doi.org/10.1016/j.margeo.2019.03.003

Smedley RK, Scourse JD, Small D, Hiemstra JF, Duller GA, Bateman MD, Burke MJ, Chiverrell RC, Clark CD, Davies SM, Fabel D, Gheorghiu DM, McCarroll D, Medialdea A, Xu S (2017) New age constraints for the limit of the British-Irish ice sheet on the isles of Scilly. J Quat Sci 32:48-62. https://doi.org/10.1002/jqs.2922

Upstill-Goddard RC, Rees AP, Owens NJP (1996) Simultaneous highprecision measurements of methane and nitrous oxide in water and seawater by single phase equilibration gas chromatography. Deep Sea Res Part I: Oceanogr Res Papers 43:1669-1682 
Van Landeghem KJJ, Wheeler AJ, Mitchell NC, Sutton G (2009) Variations in sediment wave dimensions across the tidally dominated Irish Sea, NW Europe. Mar Geol 263:108-119

Van Landeghem KJJ, Niemann H, Steinle LI, O'Reilly SS, Huws DG, Croker PF (2015) Geological settings and seafloor morphodynamic evolution linked to methane seepage. Geo-Mar Lett 35:289-304

Whomersley P, Wilson C, Clements A, Brown C, Long D, Leslie A, Limpenny D (2010) Understanding the marine environment - seabed habitat investigations of submarine structures in the mid Irish Sea and Solan Bank Area of Search (AoS). JNCC report no. 430. JNCC, Peterborough
Wingfield RTR, Hession MAI, Whittington RW, (1990) Anglesey sheet $53^{\circ} \mathrm{N}-06^{\circ} \mathrm{W}$ quaternary geology $1: 250,000$ map series. British Geological Survey

Wood D, Jenkins C, Eggett A, Judd A, Golding N (2016) CEND; cruise report: Croker Carbonate Slabs cSAC/SCI monitoring survey. JNCC, Peterborough

Publisher's note Springer Nature remains neutral with regard to jurisdictional claims in published maps and institutional affiliations. 